\title{
Fortress conservation, wildlife legislation and the Baka Pygmies of southeast Cameroon
}

\author{
Ngambouk Vitalis Pemunta
}

Published online: 25 July 2018

(C) The Author(s) 2018

\begin{abstract}
The indigenous Baka Pygmies of southeast Cameroon depend mainly on environmental incomes for their livelihoods, usually hunting and gathering and the sustainable use of their ecological systems. They are at the verge of profound political, socioeconomic, and environmental transformations orchestrated by modern state laws regulating hunting and international development actors and agencies whose development vision expressed through conservation often underlie a contradiction with their way of life. This ethnographic study aims to document the dynamics of the institution of the great hunting expedition among the Baka. An interplay between the overexploitation of forestry resources, the creation of protected areas (fortress conservation), the full protection of certain classes of large mammals, the use of specific tools forbidden by existing forestry legislation and the ruthless behaviour of 'eco-guards' have led to changes in the organization of the great hunting expedition. To better address the socio-cultural aspects of biodiversity conservation and consequently strengthen the legislation regulating the wildlife sector in the country, conservation stakeholders must be conscious of the multiple entanglements between human and other life forms and the ecology of hunting. This suggests the need for a rights-based
\end{abstract}

N. V. Pemunta $(\bowtie)$

Centre for Concurrences in Colonial and Postcolonial Studies, Linnaeus University, 35195 Växjö, Sweden e-mail: vitalispemunta@gmail.com approach to conservation that recognizes the entanglement of 'multispecies assemblages' and respects indigenous land rights.

Keywords Indigenous conservation - Sustainable development $\cdot$ Forestry regulation - Ecology of hunting - Multispecies assemblages - Pygmies . Indigenous land rights $\cdot$ Cameroon $\cdot$ Socioeconomic livelihood

\section{Introduction}

Worldwide forest bearing communities are under huge political, economic, ecological and social pressures as they confront modern state laws and international development actors and agencies whose development paradigm often underlie a contradiction between their way of life-usually hunting and gathering and the sustainable use of their physical environment (Pyyhälä 2012; Pemunta 2013; Ndameau 2001; Lueong 2017; Rupp 2003). Emboldened by the recommendations of various international conferences including among others the United Nations Conference on Environment and Development (1992) and the Fourth World Parks Congress (2003), Cameroon increased its number of protected areas to 21 (Pemunta and Mbu-Arrey 2013; Pemunta 2013). This expansion of the number of protected areas engendered the eviction, displacement, conflicts, and widespread multiple human rights 
violations from armed guards/forest protection force (locally called 'eco-guards') on the indigenous Baka people of southeast Cameroon (Pemunta 2014; Ndameau 2001:217) whose socioeconomic livelihood revolves mainly around hunting and gathering. They became "Forest people without a Forest" (Lueong 2017:2; Rupp 2003), or "virtual citizens" (Pemunta 2013, 2014). It further curtailed the availability of game that constitutes more than $50 \%$ of their source of protein (Robinson and Bennet 2000) and a central element in their ritual practices. Estimates have it that local people in the Congo Basin consume on average $100 \mathrm{~g}$ per day of protein (Wilkie and Carpenter 1999; cf Ichikawa 2006:5). Fortress conservation ${ }^{1}$ undermines nature protection, uproots local communities from their socioeconomic livelihood systems and woefully fails to protect flora and fauna (Ndameau 2001:217; Kashwan 2017; Pemunta 2013). A spike in the poaching of elephants, gorillas, and chimps has been observed in protected areas (Bushell and Eagles 2007; Stiles 2011; Kashwan 2017). There is, therefore, a paradox between the logic of conservation and the survival of indigenous peoples. In other words, dominant development models are at variance with conventional modes of production and livelihoodincluding hunting, herding, fishing and gathering (Pyyhälä 2012:12; Lueong 2017; Pemunta 2013).

Can hunting be effectively managed to conserve biological populations while meeting human needs? How has the Cameroon government's implementation of its conservation policy (as manifested through its principles and rules) deprived the Baka people, in a way that runs counter to their local vision and aims? How are the Baka Pygmies adjusting to the new economic, political and social dispensation that prohibits entry into the forest, the hunting of certain animal species as well as hydroelectric power and conservation projects that displace them?

This paper aims to analyze various mechanisms of adaptation of the Baka's great hunting expedition to changes affecting their physical environment and threatening their culture (the loss of forest myths and

\footnotetext{
${ }^{1}$ Contrary to fortress conservation which often involves the use of state violence to achieve the goal of biodiversity conservation, community based conservation-entails engaging local communities in conservation so as to mitigate conflict by providing them management responsibility and compensation to offset restricted access to land and natural resources (Karlsson 2015; Vedeld et al. 2016:183; Adam and Hutton 2007).
}

culture), socioeconomic wellbeing and livelihood. The Pygmy's great hunting expedition aims to hunt for ritual animals and the gathering of forest and nonforest products for socio-cultural purposes-particularly for the celebration of certain rites. It is at the heart of ritual practices among the people-it is intertwined with masculinity, personhood and gendered ethnic identity. The "big game hunt" (maka) is embedded in ritual ceremonies. The elephant is considered the acme of game animals among the Baka pygmies and as Joiris (1996:258) concedes: "There is a rich symbolism associated with, as the Baka say, "this really enormous beast"”. This spearhunt ceremony targeting elephants takes place during the rainy season. It implies the covering of long distances in the forest (ibid). The aim of some rites are to locate and attract game, the designation of the hunter charged with making the kill, while others facilitate tracking and/or serve as thanks-giving ceremonies to game spirits. A game ceremony is sequential involving preparatory rites, the hunting of the beast and after the kill (expiation). These rituals are associated among others with the jeng ' $l$ (rite of passage) and Béka rites (conferring secret society membership). They are complementary and reinforce each other. What makes the great hunting expedition of particular interest is that it involves most animal species classified by Cameroonian forestry law as forbidden (class A). The series of tribal ritual activities mentioned supra are witnessing changes that negatively affect the survival, identity and culture of the Baka Pygmies. These transformations are mainly orchestrated by exogenous forces engaged in energy generation, the exploitation and conservation of forest resources as well as restrictions imposed by Cameroon's forestry legislation that fail to discern the multispecies assemblages in which human and other life forms are entangled as well as the ecology of hunting among the Baka.

Below follows first, the theoretical and methodological framework informing the qualitative data collection process for this study. Secondly, is a presentation of the Baka as 'virtual citizens' whose ancestral way of life continues to deteriorate because of their displacement and uprootedness in contemporary southeast Cameroon. The third section deals with the legal context regulating hunting in Cameroon and its impact on the religious and economic life of the Baka. The fourth section describes the great hunting 
expedition ceremony as well as the conflict between conservation and this ritual ceremony. This is preceded by the conclusion to the study.

\section{Theoretical framework and method of study}

Today the Baka Pygmies of southeast Cameroon find themselves in a new socioeconomic and political environment characterized by the intrusion of State laws regulating hunting, development projects-hydroelectric and mining, sedentarization and conservation projects that prohibit access into the forest and confine them to particular spaces. A political economy framework is appropriate for analyzing the impact of these external forces on the Baka and for capturing changes over time in the institution of the great hunting expedition.

Political ecology defines the environment as a site of competition for access and control of natural resources by different social actors with asymmetrical political power. This control of the environment is concretized through the declaration and implementation of a conservation policy involving the definition and establishment of jurisdiction and frontiers defining exclusionary rights (Ichikawa 2006; Vaccaro and Paquet 2013). Different and often, powerful social and institutional actors implement while the often not so powerful (subaltern groups) such as the Baka Pygmies endure the consequences while another set of players enjoy (tourists and scientists) the benefits. Because of their productive choices, subaltern groups with strong relationships with the natural environment often endure the deleterious consequences orchestrated by sudden and radical changes resulting from conservation policies (Annecke and Masubelele 2016; Vaccaro and Paquet 2013; Adam and Hutton 2007; Peet and Watts 2004a, b; Alcorn 1993). Various actors remain entangled in "an assemblage of contradictory social relationships. These different social actors define nature, legitimacy, rights or use in very different, and culturally dependent ways" (Vaccaro and Paquet 2013:255). This power inequality which is about the definition of who exerts power and how--is also reflected in the competing knowledge systems surrounding environmental sustainability between indigenous peoples and Western scientists over the environment (Adam and Hutton 2007; Peet and Watts 2004a; Escobar 1998; Alcorn 1993). ${ }^{2}$

The renaissance of traditional ecological knowledge and customary management practices to conservation issues has spurred a spirited and contentious debate. Although traditionally Western ideas of conservation have been blended with indigenous knowledge and management ideas to come up with multicultural frameworks of action, as reflected in concepts such as co-management, the debate about whether (or not) indigenous peoples are actually conservationists (Adam and Hutton 2007; Adams 2004; Alcorn 1993) rages on. One group of scholars (Alvard 1998; Smith and Wishnie 2000) argue that actions such as resource rotation, food taboos, restrains on harvest limits, are results of optimal harvesting and not conscious conservation initiatives. They caution against the conflation of sustainability resulting from small population sizes and therefore less pressure on natural resources with conservation that is the intentional restriction of short-term goals to achieve a better long-term gain (Smith and Wishnie 2000). This debate questions the long held view about the role of indigenous peoples in conservation initiatives (Alvard 1998; Smith and Wishnie 2000; Alcorn 1993). Until the disruptive influence of agriculture, industrialization and capitalism affected indigenous communities (Smith and Wishie 2000:494; Adam and Hutton 2007; Alcorn 1993), indigenous peoples were idyllically referred to as "guardians of the environment" (Durning 1992 as cited in Smith and Wishnie 2000), and as living in harmony with nature (equilibrium-centered paradigm). Indigenous peoples are however, not "frozen in time". Peet and Watts explicitly refers to their romanticization and assumed rootedness in place as the "territorialization of history" and "a naturalization of history" (2004a:24). Although they are shapers of their environment, they have not consistently occupied the same spot. As a form of adaption to environmental changes (ecological instability), they constantly move and adapt their lifestyles to new circumstances thereby

\footnotetext{
2 The key issue is "why particular knowledges are privileged, how knowledge is institutionalized and how the facts are contested" (Peet and Watts 2004a:15) the production and reproduction of particular knowledges and practices as well as how particular forms of knowledges predominate, circulate and how over time (Peet and Watta 2004a, b).
} 
shaping environmental history. They alter the ecosystem to achieve ecological dominance using diverse practices such as periodic burning (to increase growth of plants, sowing, irrigation of wild food, plants etc) to create and maintain habitats that involves habitat modification and the domestication of their environment. These practices physically reshape earth forms, waterways as well as plant and animal communities etc. This concatenation of practices that modify the environment as a form of adaptation has been referred to as ecosystem engineering (Jones et al 1994; cf. Smith and Wishnie 2000:497; Alcorn 1993:425). While humans are agents of biological disturbance, anthropogenic disturbance is not only disruptive, if of moderate intensity and frequency, it can have biodiversity enhancing effects. Conservation is a conscious action that does not only prevent/mitigate resource depletion or environmental damage; the intent must be to do so as a form of adaptive behavior under stringent conditions (Smith and Wishnie 2000:493; Peet and Watts 2004a). The consideration of indigenous knowledge-based systems as being of conservation value is only based on two criteria (1) their ability to prevent or mitigate resource depletion, species extinction, and habitat degradation and (2) be intentionally designed to achieve that aim (Alvard 1998; Smith and Wishnie 2000; Peet and Watts 2004a; Alcorn 1993).

Ethnographic fieldwork to collect the data for this study took place in the Boumba and Ngoko regions, close to Yokadouma in the East region of southeast Cameroon during a 3 months period (June-August 2015). The study population of 78 respondents (2 focus group discussion sessions bringing together 17 respondents and 61 individual in-depth interviews) mainly among the Baka of Bidjouki. We however also extended out to the Baka Pygmies of Kounabembé village in the Moloundou region; and visited Baka camps at Banana and Bangoy. These camps are located on the periphery of the Boumba Bek/Nki National Park to the west and Lobéké National Park to the east. Most respondents were Baka initiates of the Jeng ' $l$ or Edjengui ceremony, leaders of the neigbouring Bantu population, conservation and administrative authorities. Each in-depth interview lasted for approximately an hour. Most were conducted in the French language, while a few with the help of a trained research assistant in the native language with whom the author had conducted previous ethnographic fieldwork in the region. Participation in the study was voluntary. Because of sensitivity surrounding the issue of illegal hunting in the area, respondents were assured of the confidentiality of the information provided.

A case study approach was adopted because it provides for a holistic, in-depth investigation as well as understanding of the social phenomenon of hunting and transformations in the institution from the actor's (emic) perspective (Stake 1995; Tellis 1997; Zainal 2007). It simultaneously "helps to explain both the process and outcome of a phenomenon" via "complete observation, reconstruction, and analysis of the cases under investigation" (Tellis 1997; cf. Zainal 2007:1). Qualitative accounts are suitable for exploring or describing "the data in the real-life environment, but also help to explain the complexities of reallife situations which may not be captured through experimental or survey research" (Zainal 2007:4; see also Stake 1995).

In tandem with the objectives of the study, collected data were anonymized using fictitious names, grouped thematically, coded and synthesized. Data analysis consisted of qualitative content analysis (Yin 2003; Bryman 2004). As Robert Yin concedes, data analysis consisted of "examining, categorizing, tabulating, testing, or otherwise recombining both quantitative and qualitative evidence to address the initial propositions of a study" (Yin 2003:109). External factors and internal dynamics permit us to understand changes in the present-day situation of the Baka. Apart from the takeover of their ancestral land, the Baka Pygmies are no longer isolated. These foragers now live in association with Bantu farmers and have multiple subsistent strategies (Pyyhälä 2012:18; Lueong 2017).

\section{Background: the Baka Pygmies as "virtual land owners"}

There are three broad ethnic groups of indigenous "Pygmy" peoples in Cameroon: the Baka, the Bakola/ Bagyeli and the Bedzan. The Baka Pygmies are the second-largest group in the region of southeast Cameroon. In the south and southeast of the country, they number around 25,000-30,000 people. ${ }^{3}$ They are

\footnotetext{
${ }_{3}$ Report of the African Commission on Human and Peoples' Rights Working Group of Experts on Indigenous Populations/ Communities.
} 
spread out in three regions of south-central and southeastern Cameroon: Djoum-Messaména, Abong Mbang-Lomié-Ngoïla, and Yokadouma-Moloundou axis. They outnumber the Bantu in the latter part (Ndameau 2001:220-221; Abega 1998). The Bidjouki Baka Pygmy groups are sandwiched on the frontiers between Cameroon and the Central African Republic while those in Kounabembé village are located north of the Boumba Bek National Park (BBNP).

Traditionally, they live mainly from hunting and gathering in territorial and remarkably egalitarian nomadic bands (Ngima Mawoung 2015). Over time however, they are increasingly adopting a sedentary lifestyle (agriculture) under the influence of multiple factors. Among these factors are massive deforestation and imposition from the Cameroonian state-including restrictions in the right to access and use of the forest as laid down in Cameroon's 1994 forestry legislation, and the activities of development and conservation NGOs (Djeukam 2007:4; Pemunta and Mbu-Arrey 2013; Pemunta 2013; Lueong 2017). These influences have resulted in the loss of access to essential natural resources for their biological and cultural survival. The image of the forest-the natural habitat of the Pygmies - is that of a "giant free natural supermarket" ("the [Gross Domestic Product] GDP of the poor") (Djeukam 2007:4). It "constantly provides food, medicines, construction and equipment materials, as well as ceremonial elements" (Djeukam 2007:4) for their livelihood which is intimately intertwined with the quality of forest resources. Today, intensive exploitation of forest resourcesparticularly timber, plantations, oil, mining and bushmeat in favour of the metropolis has transformed the natural habitat of forest dwellers. Weak state mechanisms, the contravention of existing regulation and corruption facilitate these activities that tend to impoverish local populations by degrading their environment (Lueong 2017; Ngima Mawoung 2015; Ndameau 2001).

As hunter-gatherers, the environment influences the Baka people. They have adopted hunting and gathering, and undertake particular ritual practices in the course of the year as a means of adaptation (Pemunta 2013; Ngima Mawoung 2015; Abega 1998). The religious system of the Baka is significantly influenced by the forest environment, which they must rationally use for their survival. They, however, also use myths, rites, and other prohibitions to protect and preserve their physical environment. These constitute what some scholars (Smith and Wishnie 2000; Alcorn 1993) describe as inadvertent measures of environmental conservation. Presently, game is increasingly becoming scarce due to a number of factors that interpellates adaptation to this new reality. First, the stepping-up of logging activities by timber exploitation companies alongside the expansion of farmlands has reduced the remaining uncut forest to "empty forests" as excessive pressure is exerted on forestry resources, including game. Secondly, the thriving commercial hunting for wild animals has consequently led to a considerable reduction in animal populations in protected areas (Ichikawa 2006:5; Pemunta 2013). Compounding the situation is the fact that 'eco-guards' tasked with preventing poaching and wildlife trafficking are, following our respondents, actively colluding with poachers (see Annecke and Masubelele 2016). Thirdly, the economic downturn of the 1980s and 1990s and the accompanying structural adjustment programme imposed on Cameroon, led to a drastic reduction in wages and unemployment. It also orchestrated reverse migration from the cities to the countryside. This development further accelerated the expansion of the bushmeat trade and endangered rare species including large-sized mammal species such as elephants, gorillas and chimpanzees (Pemunta 2013; Ichikawa 2006). As Mitsuo Ichikawa notes:

...Hunting activities in rainforests characterized by rich biodiversity will not be abandoned when the population densities of the specific game animals decrease to low levels, but will continue so long as the population densities of other game animals remain high enough. Further, if hunters encounter rare species in the process, such species will also fall prey, with the result that large-sized mammals and species with slow rates of reproduction will be exterminated first(Ichikawa 2006:6).

To understand the various transformations that have taken place both within the socioeconomic and physical environment of the Pygmies, we must situate them within the macro socioeconomic and political context of Cameroon regarding the land tenure system, energy generation projects and laws regulating natural resource management. Often, State laws including the regulation of natural resources and hunting negatively affect their wellbeing and socioeconomic livelihood 
(Pemunta 2013; Ndameau 2001:221; Pemunta and Mbu-Arrey 2013).

Cameroon has witnessed a triple colonial heritage-German, French and British colonial heritage that shaped its land tenure system. The German colonial administration (1884-1914) injected written legal norms into Cameroon's land tenure system and in the process transformed common pool resources such as forested land therein into state property using the notion of "vacant and ownerless lands" (Ndameau 2001; Djeukam 2007; Njoh 2009). The British and French colonial administrations adopted this injection of capitalist principles into the existing communal land tenure system. The transformation of the communal land tenure allowed for capitalist accumulation through the dispossession of local communities (Harvey 2003). Since then common ownership of land has henceforth been reckoned regarding mis en valeur (economic profitability/development) through cultivated fields or construction (Djeukam 2007; Njoh 2009). This created problems for indigenous huntergatherer communities like Pygmies whose nomadic lifestyle impacted very minimally on the forest cover (Abega 1998) and "their presence in a given area was difficult to establish" (Djeukam 2007:8). They became what Pemunta (2013) eloquently refers to as "virtual landowners". The 'protectionist' approach to natural resource management has marginalized rural people, the very custodians of these resources. They often have "no compensation for crop damage caused by wildlife and above all no access to the resources" (Usongo and Nkanje 2004:120). The unfettered effects of inappropriate conservation measures in local communities have been well documented (Vaccaro and Paquet 2013; Neumann 2004; Usongo and Nkanje 2004; Pemunta 2013). These deleterious effects include "conflicts through relocation, limited access, upset of household economies and property systems, alteration of divisions of labour and traditional skills. Conservation is in most cases often equated with closure" (Usongo and Nkanje 2004:120). We need to strike a balance between conservation, energy generation and the preservation of local livelihood systems.

\section{Energy generation projects and protected areas}

Various hydroelectric projects including the Lom Pangar (projected to produce 30 megawatts (MW) of electricity), the Nachtigal hydro dams and the concentration of a series of dams on the Senegal River aimed at generating and supplying energy to a more significant majority of Cameroonians come with unfettered environmental effects. Apart from various dam development projects under construction, downstream on the Senegal River are the 263 MW Edea and 396 MW Song Loulou Dams. Both currently generate 95\% of Cameroon's electricity. These energy development projects are expected to ramp up the country's power production to $3000 \mathrm{MW}$ by 2030 from the present level of $1200 \mathrm{MW}$ (Tchouaha 2012:16). The construction of these dams will however increase the country's dependence on hydroelectric power. Apart from submerging the forest and land for agriculture, this development will further spell doom and accentuate the risk of an economic breakdown in the event of drought hitting the river basin in the future. The country enjoys enormous sunshine that can be harnessed into energy. This therefore implies that the government would be better off pursuing a broader spectrum of renewable energy options. To achieve energy abundance that is accessible to remote areas of the country and other African nations, all that the government needs is political will (Tchouaha 2012).

These energy generation development projects have led to human encroachment, destroyed forestland and increased the vulnerability of Cameroon's economy to climate change (Pemunta 2013). Besides the creation of protected areas for conservation, the Pygmies have been obligated to go farming and hunting far away into the forest-where they can find something to eat (Pemunta 2013; Ngima Mawoung 2015). On the overall, these projects will threaten the biodiversity of the Sanaga River and its tributaries, its surrounding productive forest, and wildlife in the Congo Basin, as well as the survival of indigenous communities that rely on natural resources. As infrastructural development in forest areas becomes more common, the demand for land is growing exponentially (Ndameau 2001). The forest region of Cameroon is witnessing an upsurge of Chinese and other foreign business operators that are involved in timber extraction and mining, even in protected areas (Abega 1998; Pemunta 2013). Corruption ensures that these development projects never respect the rights of indigenous communities' concerning compensation (Ngima Mawoung 2015, Ndameau 2001). The Lom Pangar Dam project was for instance, mired in corruption as 
detailed by Cameroon's Anti-corruption Commission report of 2012 (Commission Nationale Anti-Corruption (CONAC) 2012).

A majority of the Baka and Bagyeli Pygmies attribute their poverty to the disturbances caused in the forest by development actors and forest exploiters (hunters and loggers) alongside conservation organizations that prevent them from gaining access. During a focus group discussion session in the Akak village in Campo, one Pygmy participant pointed out that:

There currently exist too many laws which prohibit just anything... the forest no longer has anything, and they no longer want to see us there whereas we are not the ones who have destroyed the forest.

This is an indication that developments including conservation are not improving the livelihood of the Baka Pygmies. Cameroon's 1974 land tenure legislation - the main body of law regulating land ownership in the country, has remained trapped in the Eurocentric colonial notion of "vacant and ownerless" land (Njoh 2009). This notion subsequently made state monopoly over land and natural resources the mantra of the country's land tenure system at the expense of customary institutions (Njoh 2009, Pemunta and MbuArrey 2013; Pemunta 2013, 2017). This is despite the co-existence of both official and conventional land tenure systems (see Mamdani 1996). Against this backdrop, forests were a primary target. The acquisition of bureaucratic control over forested land and timber were at the center of the politico-economic forces underpinning and shaping territorial nationstates in Africa and worldwide (Djeukam 2007; Neumann 1997). The state owns the forest and defines forest policies and regulations. Fortress conservation turn protected areas into sites of oppressive colonial practices and may play a role in the perpetuation of

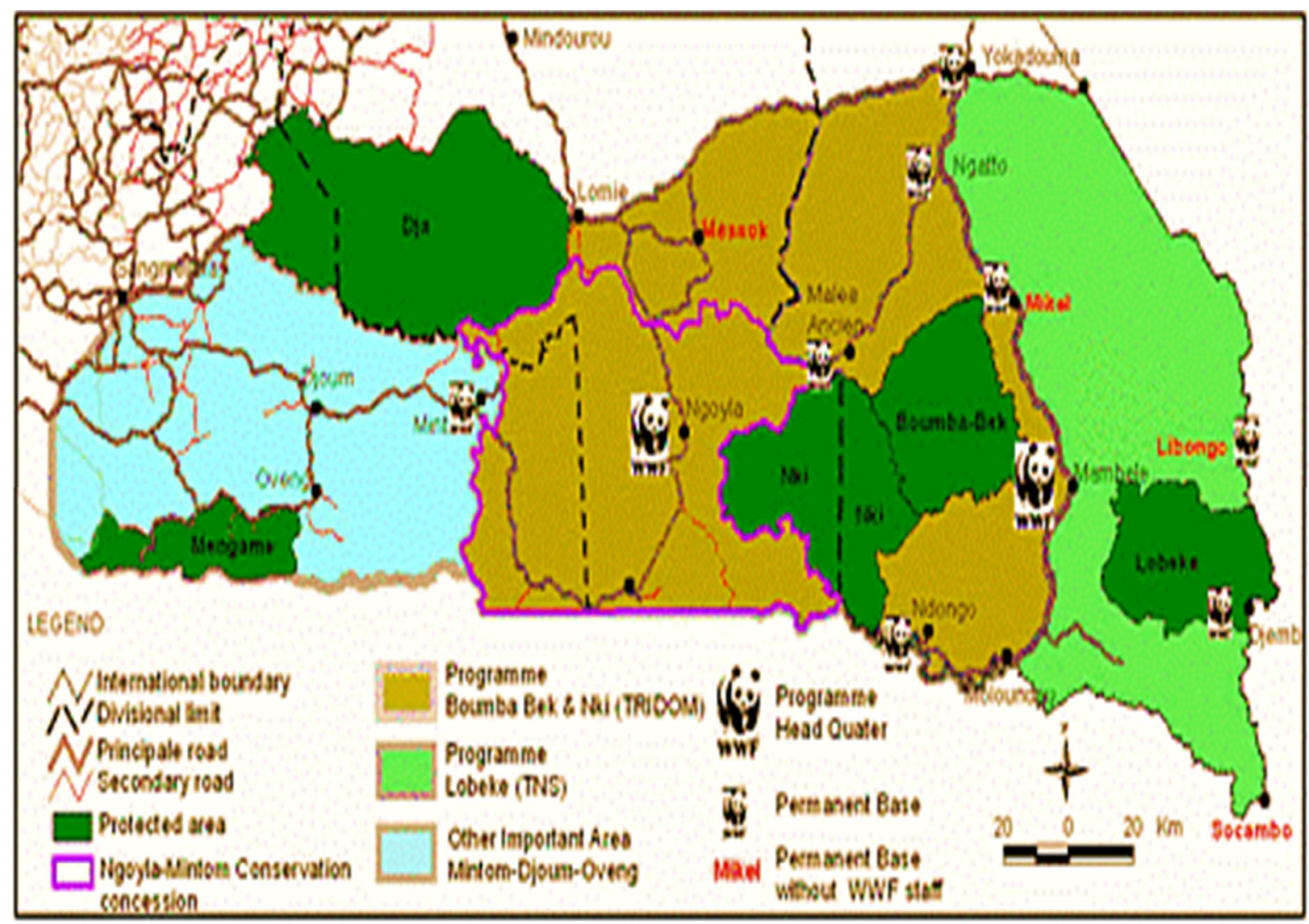

Map of Jengi project showing national parks around the Baka Pygmies. Source: http://www.wwf-congobasin.org/where_we_work/ cameroon/jengi_programme/ 


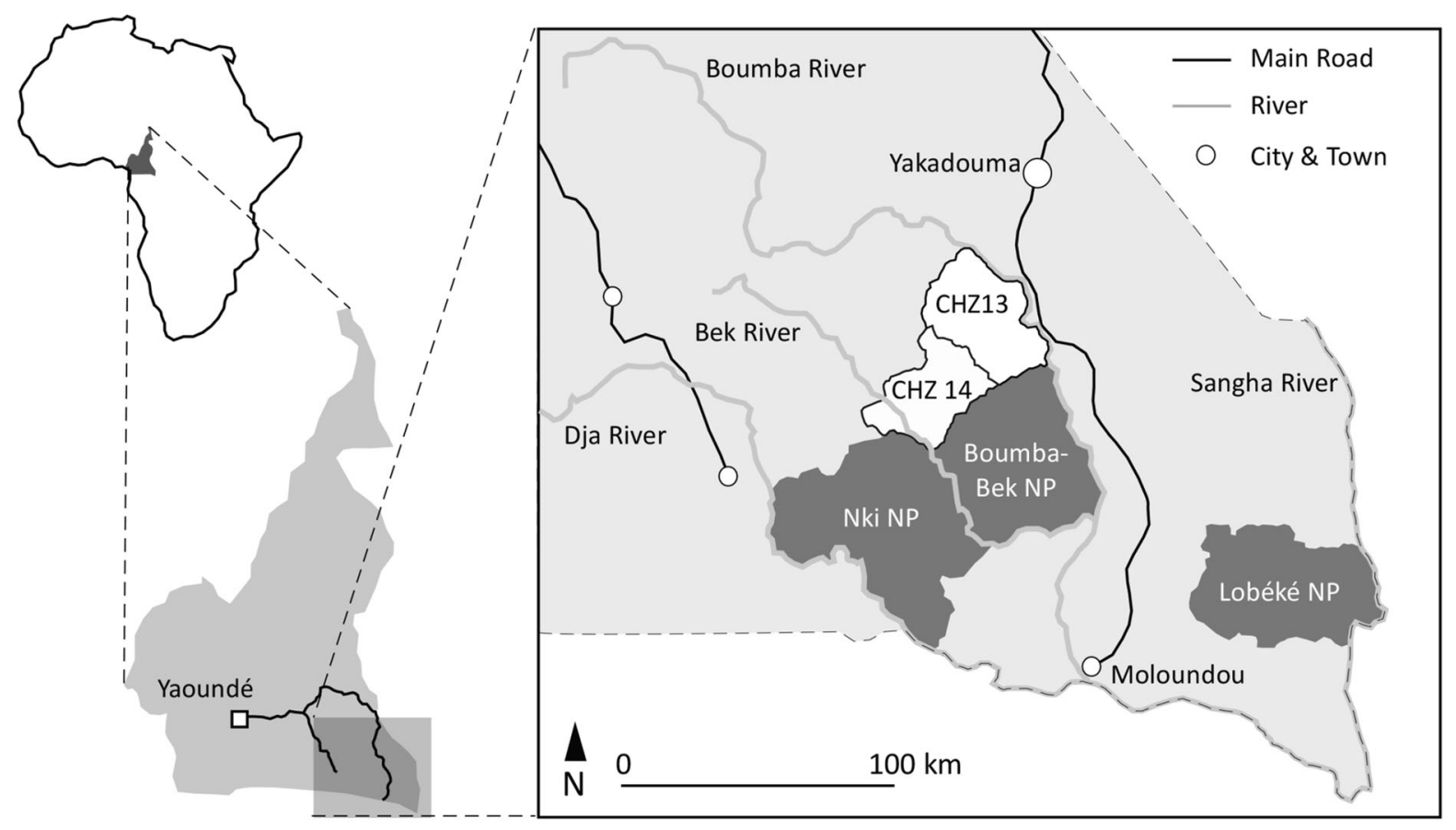

Fig. 1 Map of southeastern Cameroon showing the three national parks and community hunting zones (CHZs) 13 and 14. In addition to the main roads shown, there are many secondary roads, most of which are constructed and maintained by logging companies. NP indicates national park. https://www. ecologyandsociety.org/vol20/iss4/art25/figure1.html conflict. "Armed guards and 'shoot on sight' policy are reminiscent of colonial practices of exclusion and 'Othering' (Baines and Vales 2008; cf. Annecke and Masubelele 2016:199; Adam and Hutton 2007).

In Cameroon and most of Africa, the government owns and control forest management activities. Local communities have therefore lost local autonomy and resist incursions of the state (frontier violence), the state in turn attempts "to criminalize" local customary rights over access to, and control over, local forest products" (Peet and Watts 2004:23). Traditional hunting is accordingly equated with "game theft", or poaching, and the gathering of fuelwood with "forest felling". The lack of the voices of local people in decisions creating national parks and protected areas that inevitably come with social and economic impacts has been well acknowledged (Adam and Hutton 2007; Vaccaro and Paquet 2013; Smith and Wishnie 2000). The forest area is classified into Permanent Forest Domain (PFD) and Non-permanent Forest Domain (NPFD). By law, the PFD must cover at least 30 percent of the national territory. It is further partitioned into community forests (forêt communitaire) and state forests (forêt Dominales). Included in the latter are protected areas and logging concessions. In 2004, the PFD comprised of 8.9 million ha, which included 2.6 million ha of protected areas, 300,000 ha under community management as well as 6 million ha classified as Forest Management Units (FMU). The law further provides for community forests, which are meant to foster village-based forest resource management. It is within the FMUs created in Non-permanent Forest Domains that Community Hunting Zones (ZICGCs) and Sport Hunting Zones operate (ZICs). The Boumba Bek National Park (BBNP) is surrounded on three sides by hunting zones and PFDs with the Nki National Park (NNP) on the western side (Randolph and Stiles 2011:13-14; Ndameau 2001). Protected areas flank the Baka Pygmy people on the west (the Boumba Bek and Nki National Parks) and from the east (Lobéké National Park) (Fig. 1). The surrounding forests has been classified and intended for timber exploitation. This suggests that besides limited hunting access, the Baka Pygmies have virtually no access 
to the forest. The confinement of the Baka to particular spaces resonates with the view espoused by Rod Neumann according to which 'the war on biodiversity in Africa' frequently prioritizes the interests of biodiversity conservation above those of human beings (Neumann 2004). Once an area is designated as a national park/ protected area, it culminates not only to transformation in the control and management of natural resources but also to change in people's thinking about and how they live in that place-a change in people thereof (as such). The message is that space should be analyzed as a holistic sphere "not as a sphere out of social representations, structures and practices" (Cortes-Vazquez and Ruiz-Ballesteros 2018:37). As a site for the construction of individual and collective identities, and where social relationships are forged. Space mediates socioeconomic interests (the practical scope) and is the medium through which understanding, representation relates the individual's self to the environment (symbiotic dimension).

The voices of forest-dwelling communities are often not integrated into the decision-making structure by development NGOs and conservationists, the State or forest exploiters (Ndameau 2001:221; Pemunta 2013; Pemunta and Mbu-Arrey 2013). This highlights some of the key issues of participation, community rights and local needs that are embedded in environmental protection and conservation strategies, as well as in resource control (Peet and Watts 2004a:12; Karlsson 2015; Neumann 2004). The organization of Cameroon's forest estate is subject to the State's directives. In line with these directives-particularly the 1994 Forest law and the 1995 decree of application, the permanent forest is comprised of (1) land allocated to forest or wildlife habitat and, (2) nonpermanent forest, which includes "land available for a variety of uses" (Ndameau 2001:217). In forested areas, peoples, protected areas, and logging activities are at odds, invariably leading to tension and conflict "over the application of the law in general, and the day-to-day management of protected areas in particular" (Ibid). This speaks to competing interests between indigenous people in development within the macro frame of a forested landscape and those of biodiversity conservationists preoccupied with promoting the survival and sustainability of all species (Adam and Hutton 2007). This is the case whereas the distinction between humans and nature is false.
Additionally, there is a multifaceted perception and opposed views of the forest between the State, conservation project managers, Bantu and Pygmy. Over time, game-hunting networks have grown exponentially. Despite the enactment of laws prohibiting the harvesting of wild elephants, gorillas and many other animal species remain threatened and on the verge of extinction (Ndameau 2001:223).

\section{The legal framework regulating hunting in Cameroon}

This section examines the 1994 Forestry Law and the decree of 1995, which jointly lay down the rules for the regulation of fauna in Cameroon. It further provides some examples of the shortcomings of this body of legislation as well as set out the cultural context for understanding ritual hunting among the Baka.

The 1994 Forestry law distinguishes traditional from sports hunting. Article 85 and Article 2, paragraph 20, provides that conventional hunting is any act aimed either at the pursuit, capture or killing of a wild animal undertaken by forest dwellers, using tools made from materials of plant origin or materials derived from plants. We observed that most Baka hunters are engaged in comparatively low-efficiency hunting techniques using snare trapping, metal towcables, bore and arrows. Other tools now used for conducting traditional hunting include headlamps, vehicles, dogs, and steel cables. In other to obtain higher uptake, a few are however, increasingly using firearms supplied to them by ivory dealers (see Randlop and Stiles 2011:36). Different ways of hunting depending on various technical means might potentially have differentiated impacts on wildlife (Alvard 1998; Smith and Wishnie 2000; Peet and Watts 2004a; Alcorn 1993). The law however forbids the same individual to simultaneously lay several traps. The local population/ forest dwellers are those living in or around the forest where they have customary rights - that is to say, the right to use or the right to carry out their traditional activities in the forest including hunting. All members of forest dwelling communities are entitled to traditional hunting without the need for a permit or hunting license (1994 Law Article 87, sub 1). Although the law attributes ownership of every natural resource, 
Table 1 List of certain class A, B and $\mathrm{C}$ animals. Source: MINFOF (2006) (See: Arrêté $\mathrm{N}^{\circ} 0648 /$ MINFOF DU 10 DEC. 2006 )

\begin{tabular}{lll}
\hline Class A & Class B & Class C \\
\hline Elephant & Bongo & Hare \\
Lion & Buffalo & Porcupine \\
Panther & Sitatunga & Rat psalmist \\
Chimpanzee & Red River Hog & Hegehog \\
Gorilla & Genette & Daman \\
Brown swallow & Warthog & Rat of Gambia \\
Vulture & Duiker & Brush-tailed porcupine \\
Crocodile & Eephant (weighing more than $5 \mathrm{~kg}$ ) & Aardvark \\
Tortoise & Pigeon of Cameroon & \\
Goliath Frog & Royal Python & \\
\hline
\end{tabular}

including wild animals to the State, this is in contradiction with tradition. Besides, there is no tax to be paid by the local population.

The practice of traditional hunting is, therefore, free of charge. This is, however, the case only when the hunted or captured animal is strictly intended just for household consumption. Those who wish to hunt for commercial purposes must pay taxes, must have also sought and obtained permission or a hunting license from the administration (Law of 1994, art. 88-89). This means that in no case can game meant for subsistence be sold. Similarly, the law prohibits the traditional hunter from transporting game, even with the intention of consuming it himself or for the consumption of members of his family living in a neighbouring village or town. Thus, all products derived from the forest under the right of use in general and traditional hunting, in particular, must be consumed within the territorial limits of the vicinity of the forest.

Traditional hunting is strictly prohibited from protected areas-national parks, wildlife reserves, integral ecological reserves, hunting areas, State ranches, and zoological gardens of the State, wildlife sanctuary, and buffer zone (1994 Law, Articles 8 and 81). Traditional hunting takes place throughout the year, and the law allows it only for rodents, small reptiles, birds and other animals in class $\mathrm{C}$ (Wildlife Enforcement Decree, art. 24 (2). Indeed, the law has divided wild animals into three categories:

Class A includes rare and endangered animal species. These species are therefore fully protected and under no circumstances must they be killed or captured, including by a traditional hunter. However, their capture or detention shall be subject to obtaining a particular authorization issued by the administration in charge of wildlife for development purposes or in the case of scientific research, protection of persons or property (Art.2);

Class B includes animal species that can be trapped, captured or slaughtered only by those who are authorized to engage in commercial hunting after obtaining a permit or hunting license from the administration. These species are subject to specific management measures without which they would become rare and threatened with extinction (art. 3);

Animals in Class $\mathrm{C}$ include mammals, reptiles, and other animals than Class A and B animals (art. 4).The table below presents a non-exhaustive list of some the animals in the abovementioned categories (Table 1).

The law provides penalties for failure to respect any of the traditional hunting requirements. First, is the seizure of the animals captured or killed. In addition to this forfeiture, the person concerned may be liable to pay a fine of 50,000-200,000 CFA francs (USD\$ 100-400) and imprisonment for a period ranging from 20 (twenty) days to 02 (two) months if he sells the catch from this hunting. He is also liable to a fine of 5000 to 50,000 CFA francs(USD\$ 10-100) and/or 10 (ten) days imprisonment for all those who do not comply with the regulation on the right to use-that is to say, the one prohibiting the use of tools other than those made from materials of plant origin or to travel with game (Law of 1994, arts. 154 and 155). The Law makes provision for residents and non-residents to practice hunting as an income-generating activity called sports hunting. 
Poaching is the illegal hunting of protected wildlife species. It is practiced by both the inhabitants and people coming into the area and is in sharp contravention of the forestry legislation. During our fieldwork, we noticed that some Baka serve as guides to poachers because of their in-depth knowledge of the forest environment. They also assists in the transportation of the booty. At the ancient Song Baka camp, in the Kounabembe area, where we spent a night, evidence of this practice was clearly visible. The game traders visit the camps regularly to buy meat that is transported in the course of the night to the city. All this was happening at the close of the hunting season. This means that the Baka are somehow involved in the practice of poaching. According to Zouya (1997), poaching is sponsored at all levels of society: local populations, forest company employees, seasonal hunters from neighboring districts or countries, senior administration officials as well as native Muslim merchants from West Africa. The most sought-after products, besides the meat, are mainly trophies (buffalos, antelopes, bongos, sitatunga, ...) and animal skins (python, panther).

After reviewing the body of forestry legislation governing hunting in Cameroon, we observe that no provision of the law is devoted to ritual hunting. However, this type of hunting is distinct from traditional hunting and sports hunting and even poaching as it plays a fundamental role in cultural practices among the Baka. About the tools used and species sought, the legislator equates ritual hunting with poaching. However, the Baka Pygmies need species from this hunt to satisfy their ritual needs.

As a form of rural govermentality regime, the forestry legislation, suffers from a good number of weaknesses. First off, the category of local people in the bill is an all-encompassing label that masks and disempowers the Pygmies (Ngima Mawoung 2015). It lumps them together with the Bantu even when they differ in their cultural practices and socio-economic livelihoods systems (Pemunta 2013; Ngima Mawoung 2015). In addition, one cause of disagreement and of dispute has to do with participative management between forest communities, the State and conservation organizations. As evident by the experiences of Mali, Niger and Senegal, the state has deployed law as a form of rural control in two senses. First, by disabling community participation through various forms of state intervention and by the continuance of the colonial model of rule. The second mechanism is through the "decentralized despotism" (Mamdani 1996) of postcolonial regimes [a mirage of local participation in which] "where local structures have an iota of representativity, no powers are devolved to them and when local structures have powers they are not representative but rather centrally controlled" (Ribot 1998:4). This has led to different perceptions of participative management and inattentiveness to power relationships by each of the local peoples/ stakeholders-the Pygmies and the Bantus. The reason is the lack of any distinction between different ethnicities inhabiting the area (Pemunta 2014). Worsening the situation is the historically hierarchical relationship between the Baka Pygmies and the Bantus, in which the latter regard the former as their chattel (Pemunta 2013, Ndameau 2001).

Another effect of the 1994 Forestry Law was "the reorganization of customary space through the separation of zones, forest concessions, and protected areas" which ironically "neglected the forest residents such as the Bantus and Pygmy communities" (Ngima Mawoung 2015:150). This reorganization of space failed to discern forests-human relationships: the "co-constitution of humans and forests" and the entanglement of trees "with the life of humans" (Karlsson 2015:387). This failure partly explains why "indigenous peoples face ordeals with forest department staff and the encroachment into their ancestral territories" (Ibid). The law failed to recognize the rights of the local population as significant stakeholders in the sustainable management of the ecosystem. Legal dispositions are at variance with the customary practices of the Bantu and Pygmy population. Some limited uses of forest resources are linked to cultural taboos that ensure optimal harvesting and may have a conservation outcome (see Smith and Wishnie 2000; Alvard 1998). Respondents maintained that before both game and other forest products became scarce, they had hunting taboos surrounding animals that could be hunted and by who, and when. They were also used to digging up wild yams and replanting the stems in the ground for it to grow so that when passing there months after, they would be sure to find yams as well as fencing off particular areas of the forest to regenerate. These are clearly conscious efforts meant to conserve the environment. They can be associated with ecosystem engineering (Jones et al 1994; cf. Smith and Wishnie 2000:497; Alcorn 1993:425). Today, every forest 
resource is under pressure because of restrictions to access. The legislation on protected areas is also at odds with "the cultural beliefs of natives" (Ngima Mawoung 2015:150). For the Pygmies, hunting constitutes both the "art and "science" of their existence. The neglect of socio-economic impacts of conservation on protected area-adjacent populations in research programmes or policy formulation processes speak to what Adams and Sandbrook (2013) call the asymmetric nature of conservation science. It is about the exclusion of certain forms of knowledge claims ('data') in the policy formulation process. It articulates the 'uneven playing field' (Larson and Ribot 2007; Adam and Hutton 2007) of environmental science and policy in which elite scientific communities is favoured over various forms of 'indigenous' and local knowledge and practices (see Escobar 1998). This exclusion of other knowledges and the prioritization of scientific knowledge has been variously called "regulatory knowledge", "the power-knowledge field", "a phenomenology of knowledge" and "the politics of knowledge" (Peet and Watts 2004a:15, 16, 20, 23). Elephant hunting is at the heart of masculinity, and gendered knowledge. This explains why it is accorded significant socio-cultural value. The ambition of every male Pygmy is "to kill an elephant without any sophisticated weapon, but rather, using his bare hands or traditional weapons" (Ngima Mawoung 2015:150; Joiris 1996) to gain social recognition as well as social mobility during his lifetime. Legislation regulating hunting instead works against the joint management of national parks and leads to conflict between the Bantu and Baka Pygmy communities and conservationists (Ngima Mawoung 2015; Pemunta 2013). They are constantly fighting "for recognition" (Honneth 2010) of their cultural identity and rights of access and the use of forest as a way of avoiding disarticulation (Pemunta 2013). This suggests the need to pay attention to the intersection between economic and ecological justice (the politics of distribution) with human rights and cultural identity (the politics of recognition) (Peet and Watts 2004a:4). They are also keen on obtaining rights of recognition in the management of the forest (Ngima Mawoung 2015; Pemunta 2013; Usongo and Nkanje 2004). It is a precious resource from which they obtain environmental incomes and around which their worldview is constructed.

\section{Hunting as a religion}

The Baka Pygmies carry out their main activities in the forest located near the Boumba River to the southeast of the Boumba Bek National Park, as well as in the woods situated to the south of the Lobéke National Park (Ndameau 2001:222). The forest is central to Baka cosmology: "this is the forest that we know best" (Abega 1998; Ndameau 2001:222). In Baka worldview and mythology, the spirit Komba is 'the creator of all things' in the universe. The forest and the Baka are constitutive elements of this cosmology (Abega 1998) since $m e$ are believed to live in the forest and visit to enjoy dancing and singing with them (see Joiris 1996).

Baka men are reputed for elephant hunting and for their expertise in the checking of snare lines. Initiates of the same cohort maintain fraternal relationships and following a successful hunt, share meat with each other. They undertake beka, an important ritual ceremony through which adult men gain membership into a men's secret society. This secret organization is charged with the overall "protection of society and the maintenance of stability in everyday life in the Lobéke forest region" (Rupp 2003:48).

The Jeng ' $l$ cult constitutes the most sacred ceremony for Baka men. Jeng ' $l$ also designates a prominent Baka forest spirit. The ceremony takes place through several stages and over several months. "Male initiates live together in an isolated camp in the forest" (Rupp 2003:49). They are indoctrinated and socialized on the roles and responsibilities of adults in society. They are also taught hunting techniques and spiritual life. Initiation into Jeng ' $l$ is at the heart of the process of becoming a man among the Baka. According to Bahuchet (1992:288-89), the ritual instruction culminates in the ritual killing of the initiates. They are, however, concurrently reincarnated (reborn) during the culmination ceremony as adult men, ready and capable of fully participating in the social life of the community. Baka men are imbued with power and protection to survive in the forest (Joiris 1998:186). Over time, the age at initiation has progressively decreased. Parents are now keen on imparting to their children the values they hold "dearly while they feel they still have some sway over the younger generation. At a jeng' $i$ ceremony in 1998 a young Baka boy, approximately 2 years old, was initiated" (Rupp 2003:49). Renowned Baka elephant hunters are the 
ritual guardians of jeng ' $i$, the forest spirit (Joiris 1996:271, 1998).

Jeng ' $i$ is considered "the signature spirit into whose ritual community adult Baka men expect to be initiated," (Rupp 2003:51). The word jeng ' $i$ has two meanings. It is necessarily a compelling forest spirit but also the name of ritual ceremonies in which the spirits ('me') are exhorted to visit the village from the forest.

\section{Economic life}

Now forcefully settled around the roadside and close to their Bantu neighbours, the Baka continue to shuttle between the forest and their roadside settlement, depending on the season and the type of natural/forest resources they require for their socio-cultural life. They undertake agriculture either for themselves or for the Bagando people, hunting, searching for honey and the gathering of forest products. Timber companies sometimes hire a few for their in-depth ethnobotanical knowledge in locating specific tree species for logging. As Ndameau (2001:221) concedes, "they still follow the rhythm of the seasons, and move into the forest for variable lengths of time, depending on what they are looking for during any one trip". At times, they are also sought after by safari companies to accompany sports hunters. Still, others are bankrolled to work for conservation and development projects by organizations including the Worldwide Fund for Nature (WWF) and the German Technical development Cooperation (GTZ) (see also Ndameau 2001).

The Baka depend mainly on the forest for food, shelter, fuel, and medicine and the selling of nontimber forest resources provide extra cash, which serves as valuable 'economic cushions' against financial hardships. Even more important is that the forest serves far more than a mere economic breadbasket; at the heart of the Baka belief system, it serves as a spiritual sanctuary.

The Baka also undertake small-scale fishing, search for honey, gathering activities, and trading in animal products. An elderly man explained that there has been a shift over time from spear and net hunting adopted from Bantu farmers to snare hunting targeting mostly red duikers. They nonetheless, still practice collective spear hunting with their major target being bush pigs as well as when neither steel wires nor firearms are available. Most indigenous people of the region, but even most of the Baka Pygmies who are mostly hunter-gatherers undertake this type of hunting. To adapt to ecological conditions, especially forest degradation that has led to the extinction of some game species, most indigenous peoples of the region including the Baka practice hunting with a variety of tools: traps, electric cables, crossbows, nets, etc. The number of traps varies from one hunter to another. Elders however conceded that trapping is a recent practice among the Baka and that group hunting is the most widely used method. Through the revenue accruing from hunting, the Baka satisfy $80 \%$ of their needs (Ndameau 2001). In line with the 1994 forestry law, there are three categories of small-scale hunting: depending on the nature of the material used, (generally steel cables), the hunted or captured animals (which also include protected animals), and the sale of the kill. Unlike the Bantu, the Baka are primarily dependent on hunting as the primary source of their income, as well as on artisanal fishing and the collection of wild fruits.

In interviews, WWF officials continually emphasized that they were not against the Baka hunting even inside protected areas, provided they were not using firearms. WWF has entirely banned hunting with short guns inside protected areas. In the same light, the 1994 forest law has officially outlawed a significant method of hunting among the Baka-snaring with steel wires. Despite this prohibition, this method of hunting remains widespread.

\section{Conservation and the great hunting expedition}

In Africa, the idea of wildlife conservation remains trapped in the colonial mentality-exclusionary preservation and therefore enmity between people and wildlife-even when the cohabitation between people and wildlife is not antithetical to conservation (Pemunta and Mbu-Arrey 2013; Kashwan 2017). Turning people into nature's enemy has dominated conservation initiatives in "Africa where national parks and game reserves were largely modeled after the American approach: fortress-style ecosystems that people can visit but not live in so that animals can dwell in virtually "unspoiled environments".

\footnotetext{
${ }^{4}$ https://news.mongabay.com/2016/08/does-prohibiting-localaccess-to-nature-hurt-african-wildlife-conservation/.
} 
Transformations in the institutional, socioeconomic and ecological environment in Cameroon's forest region orchestrated among others by the 1994 Forestry Law, the economic downturn of the 1980s, and climate change has, among other factors, led to changes in the Baka's great hunting expedition. Elephant hunting ceremony (Yéli) which is usually preceded by rituals performed by elders, and which often capitalize on the demands of the illegal ivory and bushmeat markets is becoming an obsolete ceremony (Kent 1996; Stiles 2011). Elders report that they are increasingly unable because of fortress conservation, which restricts access to the forest to transmit traditional hunting skills to their children.

The establishment of the park means that we are in an enclaved zone. Although the park has its boundaries here, we, the autochthones are prohibited. from clearing the forest for agriculture. They have forced people to come and live along the roadside. How can I have access to between 4 to 5 hectares of farmland? In addition, elephants constantly destroy crops. We are unable to transmit our cultural knowledge, knowledge of traditional medicine and hunting skills to our children (Baka man, Amana).

Before the coming of loggers (timber exploiters), when you went out for hunting, you did not make up to a kilometer without returning with game, but today we cover great distances and sometimes return with nothing, not even a rat mole. As you know, the Pygmies live by eating bush meat, but today we have become like the Bantus who eat vegetables. We are now like animals eating grass (Mvemle Pierre).

The restriction of access to the forest has led to the loss of local knowledge that poses a threat to the identity of this people. Cameroon boast of $19,631,000$ ha of forest (Pemunta and Mbu-Arrey 2013). Only a meager $4 \%$ of this amount is reserved for forest communities while the rest has been allocated to private commercial timber operations and reserves-overlapping the traditional use zones are least 2638 communities (Mbile 2009). Simultaneously aggravating the situation are timber concessions, protected areas, and reserves as well as mining allocations. As a result, these communities- many of which are Baka-are, according to national law, unable to expand their livelihood options or continue with traditional land- use practices (Pyyhälä 2012:42; Pemunta and MbuArrey 2013).

Cameroon's somewhat initially blind subscription to hyper-conservationism that required the complete eviction of local peoples from so-called 'national parks' and 'conserved' forest systems was misguided. Studies that question the rational basis of exclusionary conservationism suggests that forest growth and regeneration are to a considerable extent, linked to everyday human activity, and the direct environmental acumen of local indigenous peoples (Smith and Wishnie 2000; Peet and Watts 2004a; Alvard 1998; Alcorn 1993). Humans are fiercely attached to their environment, maintain symbiotic relationships as well as responsibility with multiple beings: "other-thanhuman-beings" (Karlsson 2015:381). They maintain social and cultural relationships with their environment that are formed and transformed amid encounters with multiple species of plants, animals, fungi, and microbes' (Kirksey 2014:1-2, cf. Karlsson 2015:381). Below, I describe the various stages involved in the preparation and execution of the Baka's great hunting expedition. Thereafter, I examine how the changed socioeconomic and political context is affecting the Baka.

\section{The Baka's great hunting expedition ceremony}

Rituals ensure peace and harmony as well as the affirmation of cultural values in society. Ritual substances (game captured during the great hunting expedition and other forest products) are used in celebrating ceremonies among the Baka. The great hunting expedition is a specific hunting expedition for the celebration of the rite of passage $\left(\operatorname{Jeng}^{\prime} l\right)$ or circumcision (beka). In bygone days, Jeng' $l$ was preceded by the organization of numerous rites and a long trek into the forest to hunt the elephant as a precious game (Joiris 1996). Respondents conceded that these hunting ceremonies are multifunctional: (1) establish protection for hunters against wild animals and evil spirits, (2) the regulation of conflict, including those associated with witchcraft, (3) the designation of the master hunter. It further involves methods for determining the direction from which hunters should look for and attract game, and the person to make the kill during the hunt, as well as the thanks-giving 
ceremony to the spirits (preceding the hunt) (see also Joiris 1996).

Ritual associations of initiates sharing a link with certain spirits perform the Abalè, Buma and Yéli rituals/"dances"/ceremonies that consists of activities before, during and after the hunt. The celebration of these rituals prepare the hunters and ensure the success of the expedition (Joiris 1996). With variations among Baka groups including the Bidjouki and Kounabembé of southeast Cameroon that we studied, the great hunt is a longstanding ancestral ritual. Special relationships exists between initiates and the spirits of the deceased (ancestrality-spirit). Although the master hunter (tuma) and the lineage elder (mbai) are responsible for the organization of the hunt, each ceremony has its specific characteristics.

\section{Abalè dance/rite $(b e)$}

This public ceremony takes place in the courtyard of the encampment and in the presence of a choir of singers (Joiris 1996). Surrounding a big fire, the initiates dressed in masks of Abalè, perform the dance steps to the rhythm of the drums, the clapping of hands and the singing of Abalè songs. Respondents reported that the master-hunter, Abalè nganga (main/specialized initiates/ritual agent) who has visionary powers that indicates the direction that the hunters will take performs the ceremony. This can be done either orally or through trance. The nganga goes into a light trance and when his gaze crosses that of a spirit $\left(m e^{5}\right)$ or that belonging to an animal, he sees his shadow (molili) or that of an animal (Joiris 1996). The nganga is henceforth in a position to determine the direction to be taken by the hunters. Through telepathy, the spirits of late nganga intervene during the Abalè ceremony. This ceremony is repeated severally or in sequence within the space of a few days, including in the evening preceding the departure of the hunters. Joiris (1996) concedes that the spirits that appear in the form of masks are made of plants/ vegetable materials or tissues. These spirits utter particular sounds. During the ceremony, the spirit of Abale is visible mostly through the medium of fire. Preceding the great hunt is a private rite that is being celebrated outside the camp.

\footnotetext{
5 They are tutelary spirits and anthropomorphic figures, of human origin and are therefore not animal spirits (Joiris 1996:256).
}

The Yéli female cynegetic ceremony

This female ritual ceremony is mainly associated with large-game hunting, especially elephant (Joiris 1996:249). Initiates are generally the wives of hunters preparing to take part in the next expedition. Unlike Abalè which is celebrated in the courtyard of the camp and therefore publicly (during the day or at night), Yéli is celebrated out of the camp, precisely on the path to be taken by the hunters. The uninitiated only participate by listening to the songs performed by initiates.

Following our respondents and as corroborated by Joiris (1996) the Yéli fulfills two functions- to attract and to locate animals. According to respondents, the power of the Yéli originates from the polyphonic voices of women. The songs are alleged to charm the game, that are then located through divination. Songs constitute a powerful mechanism for attracting animals (Joiris 1996:93). The vocal polyphonic voices of the initiates is associated with the power to simultaneously attract animals and to serve as a hunting charm. A soloist leads the singing and the songs are dedicated to the preparation of the hunt. The rite symbolizes the kinship relationship between the nganga who prepares the hunting and the hunters. Participants consume the Yéli hunting medicine. The aim is to fortify the charming properties of the game. Initiates use a special liquid to oil the throat and facilitate the singing of the song.

The rite also constitutes the practice of divination that is relevant to the interpretation of phenomena related to hunting as well as the rubbing of remedies (leaves and barks of trees) in the palm of the most competent nganga that permits him to determine the location of game. Each of the initiates repeat the same procedure with his own personal remedies. To reassure himself of the effectiveness of the operation, the main nganga burns young tree branches and the direction of the smoke indicates the path the hunters will have to take.

The designation of the master hunter takes place at dawn when the hunters assemble around the Yéli nganga. This ritual somehow reinforces the Abalè ceremony. It also involves a mediumship technique that comprises of falling into a trance during which the Yéli nganga hands over the walking staff (mojuma) to the master hunter. In a bid to facilitate the approach of hunters towards game, the Yéli nganga applies a medicine for invisibility (molombi) on the hunter's 
faces, on their spines and all over their body. To facilitate the progression of hunters towards the game, all inhabitants of the camp consume the same concoction.

\section{The Buma}

This rite has similarities with the Abalè public ceremony. Nevertheless, contrary to the Abalè, it involves divination with the use of fire or smoke. Our respondents told us that the Buma ceremony consists essentially of songs and dance. According to Joiris (1996:129), initiates are guardianships of spirits (former elephant hunters). Women sing while 2 or 3 initiates perform the steps. During the execution of the dance, their choreography comprised of bells knotted to their calves is accompanied by the polyphonic songs of the initiates, the drumbeat from drums, clapping of hands and rattles. As in Yéli ceremony, women occupy a significant position in the celebration of the Buma, reason why they are called mothers of Buma. They play the role of soloists but, exceptionally, some of the initiates dance like men. The Baka maintain that within this ceremony, the couple made up of the Buma initiate and his spouse prepare remedies that are supposed to invigorate the celebrants of the rites or those undertaking the hunting expedition. The success of the dance and the preparation of the hunting depends on the harmony of the collective songs with the dance steps and the beating of the drums. The song embodies the power of attraction for the game. The remedies ingested by the nganga are supposed to facilitate singing, dancing and hunting. Made of herbs and barks of trees, these remedies are inoculated in the throat and hips so that the voices of women and the bells are in harmony.

At the end of the Buma ceremony, initiates distribute small packets of a crushed bark of tree (mokobaka) to all hunters and not only to the master hunter, as is the case with the nganga of Yéli and Abalè. This remedy is placed in the hunting charm that is attached around the hunters arm. There has been a gradual disappearance of the big-game spear-hunting over time, reduced human mobility through legislation and a heightened recourse to collective net hunting. These forces have contributed "to the erosion of rites formerly associated with the hunt" (Joiris 1996:269). However, contemporary ceremonies occur prior to, during and after the hunt.
At first sight, the Baka's great hunting expedition can be equated with poaching insofar as it violates the law regarding the species of animals hunted and the hunting territory. However, the great hunting expedition among the Baka cannot be equated with poaching in the sense that it targets only animal species that are necessary for the celebration of special rites and it is undertaken just for a specific period. Various transformations in the Baka's environment has greatly affected the organization of the great hunting ceremony.

\section{The great hunting expedition and environmental change}

The focus of this study is the various mechanisms of adaptation of the great hunting expedition to the effects of various institutional, socioeconomic and ecological changes affecting the Baka's environment.

Since their settlement in the Equatorial forests of the Congo Basin some 40.000 years ago, forest dwellers have continued to hunt (Ndameau 2001). Today, this practice has become even more widespread and intensive, because of the reduction in the forest hunting surface area in the Equatorial forest. By inducing a decline in the animal population, this shrinking of the hunting surface area has limited games/resources at the disposal of hunters (Ichikawa 2006:6; Ndameau 2001). Improved access to previously untouched forest blocks facilitates the hunting and marketing of game and triggers a host of social, technological and economic changes that intensify the pressure on hunting in general and on the great hunting expedition in particular (Randolph and Stiles 2011; Ndameau 2001).

The socioeconomic environment has tremendously changed. The increase in the human population and sedentarization have created new needs. ${ }^{6}$ Massive immigration in some areas has created further disruptions to traditional hunting, greater need for arable land, increased hunting pressure on more limited areas

\footnotetext{
${ }^{6}$ Concerted efforts towards sedentarization have not turned the Baka away from their culture and tradition. They are still involved in their traditional livelihood activities of hunting and gathering. They speak their own language, practice their traditional rituals, and are largely holding out to their traditional religion despite concerted efforts by Christian missionaries to convert them to Christianity (Pyyhälä 2012:14).
} 
and a decline in the population densities of the specific game animals (Ichikawa 2006). These transformations are associated with rupture from a cultural perspective. This is partly because taboos restricting the hunting of certain animal species are being increasingly no longer respected, and hunting techniques are evolving to meet up with profit-making objectives, rather than selfsufficiency. Regardless of the potential of the densities of the specific game animals, steel guns and cables are commonly used. Hunting has become a "business," practiced both by natives but also by non-resident hunters. In the face of the chronic economic crisis of the 1980s and 1990s, forest bearing communities resorted to exchanging game meat and skins for the cash needed to purchase consumer goods and to pay for healthcare and school fees (Pemunta 2014; Ichikawa 2006). Members of these communities have also used their skills and knowledge to collude with non-resident hunters in their poaching, receiving income and other material benefits in return. Moreover, the increase in income induces an increase in the demand for game meat in the forest zone. Multiple pressures including "population growth, increased access to forests by outsiders, use of modern firearms, illegal trade in species, forest degradation, etc." are responsible for the depletion of the game (Pyyhälä 2012:33). Despite changes, hunting remains at heart and is an integral component of the diversifying livelihood and tradition of the Baka. Overhunting and the resultant depletion of various biological species in the forest is mostly the handiwork of neighbouring Bantu populations (outsiders). The Bantu maintain paternalistic relations with the Baka (Pemunta 2013; Pemunta and Mbu-Arrey 2013). This is especially the case because every Baka family is attached to a Bantu family. Relationships are also based on the exchange of services, including labour. Generally, the Baka are consistently cheated in these exchanges. They are frequently victims of multiple forms of abuses by the Bantu: exploitation of their labour force without commensurate remuneration, confiscation of their cocoa farms, low price purchase of their hunted game, beatings and humiliations in public, insult of any kind in the presence of foreigners, irreversible exchange of woman (Ngima Mawoung 2006; Pemunta 2013; Pemunta and Mbu-Arrey 2013). Additionally, as 'masters' the Bantus often compel the Pygmies by distributing guns-automatic rifles (short guns) to hunt for them. Several studies conducted on
Cameroon's forests eloquently demonstrate the intensive nature of logging and wildlife hunting, which have a definite influence on all forest ecosystems (Pyyhälä 2012; Pemunta 2013; Pemunta and MbuArrey 2013). To overcome this overexploitation, the state of Cameroon among other measures created protected areas and the fight against poaching was intensified within the context of the Jengi project of the WWF in Southeast Cameroon. However, actions geared towards nature conservation requires a thorough knowledge of all hunting activities, of the ecology of hunted species, and of the cultural, economic and political environment of the peoples of the forest (Karlsson 2015).

Various violations of the 1994 forestry law by Baka hunters regarding the tools used, species harvested and the use of traditional hunting products have been noted among the Baka (Ngima Mawoung 2015; Hayashi 2008). Hayashi (2008) has deplored the regulation of conventional hunting by public authorities. She maintains that hunting regulations that fail to take cognizance of the use of animals by the local population would ruin their livelihood and culture. This echoes the view that conflict between protected areas and people invites for a vision of conservation that incorporates new narratives-at the intersection between the ecological and the social. This is partly achievable through challenging the persistence of fortress, neoprotectionist and other top-down forms of conservation, and through a recognition that conservation is deeply rooted in (human, non-human and more-than-human) senses of place:"(a 'multispecies assemblages'), lives of humans and other species are intertwined biologically, culturally and politically"(Aisher and Damodaran 2016:293). This calls "for deep relational analyses of human interactions with other life forms by focusing attention among others on multispecies histories, and forms of knowledge rooted in place"(Aisher and Damodaran 2016:293; 2007; Karlsson 2015; Vedeld et al. 2016). On the contrary, an increase in hunting activities resulting from an influx of outsiders into the area would instead lead to the depletion of forest resources. "The solution should be found in an intermediate position between two extremes" (Hayashi 2008:4).

Commercial hunting among some forest tribal groups in southern Cameroon influences community myths and ritual practices. Myths and ritual practices serve as a mechanism for regulating the hunting of 
wildlife species. In line with Vayda and Rappaport (1967) and Rappaport (1968) (as cited in Peet and Watts 2004a:8) with respect to their environment, rituals provide tribal subsistent groups with "adaptive structure". Various rituals, symbolic and religious practices are embodiments of the native's "cognitive model" of the environment - that could elicit adaptive behavior understood in terms of the "operational models of western ecology". In this light, the pig killing rituals of the Tsembaga Maring of highland Papua New Guinea could function as a thermostat preventing over population by pigs and maintaining some sort of environmental balance with their fragile ecology (Peet and Watts 2004a:8).

Consequently, the disappearance of these myths and community rites is a handicap to the sustainable management of wildlife. The predominance of hunting compared to other activities in the region, the large number of hunters arrested by the 'eco-guards' and the assistance that the local communities render to the non-resident hunters in return for some benefits shows the danger posed to fauna. This collusion is a form of resistance. It shows that while conservation often comes with direct local costs, there are little economic benefits in return to protected area adjacent-populations that are inordinately affected. It further demonstrates that the dispossession and adverse economic outcomes that local people suffer because of conservation leads to anti-conservation attitudes among them. In the long term, these attitudes tend to "ultimately challenge the sustainability of both the regional and global public goods" afforded by conservation efforts (Karlsson 2015:181; Annecke and Masubelele 2016). With the heightening of commercial hunting (hunting for the market) that emphasizes numerical value, cultural prohibitions are beginning to disintegrate (Ngima Mawoung 2015). Compounding the situation is the use of 'eco-guards', a form of military intervention, green militarization, green securitisation that may defeat the goal of conservation for all people and further alienate local people from conservation. Although they have ensured the reduction of detrimental wildlife trafficking (Annecke and Masubelele 2016:197), locals reported that apart from extortion on the least pretext, they were active participants in illegal wildlife crimes. Military intervention is fraught with social issues including human rights violations resulting from the difference in ethics between civilian populations, conservation and the national armed forces (Oksanen 2005; Sarkar and Montoya 2011; cf. Annecke and Masubelele 2016:198; Neumann 2004). They exclude the prospects of cooperative management. They tend to reproduce inequalities and are therefore complicit with conservationists through violent exclusions that instill fear and resentment (Annecke and Masubelele 2016; Neumann 2004; Adam and Hutton 2007).

\section{Conclusion}

Changes in the Baka's environment has led to modifications in preparatory ceremonies preceding the great hunting expedition. There have been modifications in the tools and methods of hunting. The spear has given way to the rifle, certain ritual animals including the elephant have been substituted with others including duikers. There has also been the modification of the hunting territory, season and the species hunted. Unlike in the past, both Baka and nonBaka hunters now participate together in the great hunting expedition. As we move from the depths of the forest towards the town of Yokadouma, the ceremony as well as individual rituals are gradually being less practiced. Apart from the use of hunting tools forbidden by existing forestry legislation during the great hunting expedition, the Baka also hunt fully protected species. The overexploitation of forestry resources, energy generation projects, the creation of protected areas, the full protection of certain classes of large mammals, and the behaviour of 'eco-guards' somehow constitutes obstacles to the practice of the great hunting expedition.

Restrictions on access to the forest has orchestrated the disappearance of the great hunting expedition. The weaning and transformation of the various ceremonies entail the loss of vitality of ritual practices that negatively influences the education, health and matrimonial system. It has further weakened economic production as well as traditional methods of maintaining ecological balance through taboos and myths that have a conservation outcome (see Alvard 1998; Smith and Wishnie 2000). The factors responsible for these changes include-fortress conservation, multiple development actors, the setting up of energy-generation infrastructure, human encroachment, forest degradation, the poaching of animals and sedentarization 
that have tended to displace the Pygmies and to disrupt their cultural traditions.

The existing legal framework has failed to pave the way for a participatory approach to forestry conservation and management. This calls for concerted social dialogue with local communities that are confronted with the contradictions between modern conservation/hegemonic model of nature conservation and ethnoconservation. It emerges from this study that nature conservation requires deep understanding of all hunting activities, of the ecology of hunted species, and of the cultural, economic and political environment of the peoples of the forest (Karlsson 2015).

Open Access This article is distributed under the terms of the Creative Commons Attribution 4.0 International License (http:// creativecommons.org/licenses/by/4.0/), which permits unrestricted use, distribution, and reproduction in any medium, provided you give appropriate credit to the original author(s) and the source, provide a link to the Creative Commons license, and indicate if changes were made.

\section{References}

Abega, C. S. (1998). Pygmées Baka, le droit à la différence. Yaoundé: Presses de l'Université Catholique d'Afrique Centrale.

Adam, W. M., \& Hutton, J. (2007). People, parks and poverty: Political ecology and biodiversity conservation. Conservation and Society, 5(2), 147-183. Available from: http:// www.conservationandsociety.org/text.asp?2007/5/2/147/ 49228.

Adams, W. M. (2004). Against extinction: The story of conservation. London: Earthscan.

Adams, W. M., \& Sandbrook, C. (2013). Conservation, evidence and policy. Oryx, 47(3), 329-335.

Adams, W. M., \& Hulme, D. (2001). Conservation and communities: Changing narratives, policies and practices in African conservation. In D. Hulme \& M. Murphree (Eds.), African wildlife and livelihoods: The promise and performance of community conservation (pp. 9-23). London: James Currey.

Aisher, A., \& Damodaran, V. (2016). Introduction: Humannature interactions through a multispecies lens. Conservation \& Society, 14(4), 293-304.

Alcorn, J. B. (1993). Indigenous peoples and conservation. Conservation Biology, 7(2), 424-426.

Alvard, M. S. (1998). Evolutionary ecology and resource conservation. Evolutionary Anthropology, 7(2), 62-74.

Annecke, W., \& Masubelele, M. (2016). A review of the impact of militarisation: The case of Rhino Poaching in Kruger National park, South Africa. Conservation and Society, 14(3), 195-204.

Bahuchet, S. (1992). Spatial mobility and access to the resources among the African Pygmies. In R. Casimir (Ed.), Mobility and territoriality social and spatial boundaries among foragers, fishers, pastoralists and peripatetics (pp. 205-257). New York: Berg.

Baines, G., \& Vale, P. (Eds.). (2008). Beyond the border war: New perspectives on Southern Africa's late cold war conflicts. Pretoria: University of South Africa Press.

Bryman, A. (2004). Social research methods (2nd ed.). New York: Oxford University Press.

Bushell, R., \& Eagles, P. F. J. (Eds.). (2007). Tourism and protected areas: Benefits beyond boundaries. Gateshead: Athenaeum Press.

Commission Nationale Anti-Corruption (CONAC). (2012). Rapport Sur L'etat de la Lutte Contre la corruption au Cameroun. Available: http://www.conac-cameroun.net. Accessed September 22, 2017).

Cortes-Vazquez, J. A., \& Ruiz-Ballesteros, E. (2018). Practising nature: A phenomenological thinking of environmentality in natural protected areas in Ecuador and Spain. Conservation and Society, 16(3), 232-242.

Djeukam, R. (2007). Le cadre législatif et réglementaire de l'utilisation des produits forestiers non ligneux au. Cameroun. https://doi.org/10.1007/s13280-012-0347-5.

Escobar, A. (1998). Whose Knowledge, whose nature? Biodiversity, conservation and the political ecology of social movements. Journal of Political Ecology, 5(1), 53-82.

Harvey, D. (2003). The new imperialism. Oxford: Oxford University Press.

Hayashi, K. (2008). Hunting activities in forest camps among the Baka Hunter-gatherers of Southeastern Cameroon. African Study Monographs, 29(2), 73-92.

Ichikawa, M. (2006). Problems in the conservation of rainforests in Cameroon. African Study Monographs, Supplement 33, 3-20.

Joiris, D. V. (1996). A comparative approach to hunting rituals among the Baka (Southeast Cameroon). In S. Kent (Ed.), Cultural diversity among twentieth century foragers: An African perspective (pp. 245-275). Cambridge: Cambridge University Press.

Joiris, D. V. (1998). La chasse, la chance, le chant. Aspects du système rituel des Baka du Cameroun. These de doctorat, Universite Libre de Bruxelles.

Jones, C. G., Lawton, J. H., \& Shachak, M. (1994). Organisms as ecosystem engineers. Oikos, 69, 373-386.

Karlsson, B. G. (2015). Political ecology: Anthropological perspectives. In J. D. Wright (Ed.), The international encyclopedia of the social and behavioral sciences (2nd ed., pp. 350-355). Oxford: Elsevier Ltd.

Kashwan, P. (2017). Inequality, democracy, and the environment: A cross-national analysis. Ecological Economics, 131(C), 139-151.

Kent, S. (Ed.). (1996). Cultural diversity among African pygmies. In Cultural diveristy among twentieth-century foragers: An African perspective (pp. 1-18). Cambridge: Cambridge University Press.

Kirksey, E. (2014). The multispecies salon: Gleanings from a para-site. Durham: Duke University Press (Second edition printed in December 2015).

Larson, A. M., \& Ribot, J. C. (2007). The poverty of forestry policy: Double standards on an uneven playing field. Sustainability Science, 2(2), 189-204. https://doi.org/10.1007/ s11625-007-0030-0. 
Lueong, G. (2017). The forest people without a forest: Development paradoxes, belonging and participation of the Baka in East Cameroon. New York: Berghahn.

Mamdani, M. (1996). Citizen and subject: Contemporary Africa and the legacy of late Colonialism. Princeton: Princeton University Press.

Mbile, P. (2009). Rights Contestations through Community Mapping in Cameroon. Washington: Rights and Resources Initiative.

Ministère des forêts et de la faune (MINFOF). (2006). Direction de la faune et des aires protégées., L'Arrêté $n^{\circ}$ 0648/MINFOF du 18 décembre 2006 fixant la liste des animaux des classes de protection A, B, C. Nous y ferons référence en tant que «l'Arrêté ». Available from: http:// laga-enforcement.org/Portals/0/Documents/Legal\% 20documents/Cameroon/1\%C3\%A9gislation\% 20faunique_Protection_esp\%C3\%A8ce_menac\%C3\% A9es-Fr_En.pdf. Accessed 20 June 2018.

Ndameau, B. (2001). Protected areas and Indigenous peoples: the paradox of conservation and survival of the Baka in Moloundou region (south-east Cameroon). Case Study 7: Cameroon-Boumba Bek. Available at: http://www. forestpeoples.org/documents/africa/cameroon_dja_b_ bek_eng.pdf.

Neumann, R. P. (1997). Forest rights, privileges and prohibitions: Contextualising state forestry policy in colonial Tanganyika. Environment and History, 3(1), 45-68.

Neumann, R. P. (2004). Moral and discursive geographies in the war for biodiversity in Africa. Political Geography, 23(7), 813-837.

Ngima Mawoung, G. (2006). Perception of hunting, gathering and fishing techniques of the Bakola of the coastal region, southern Cameroon. African Study Monographs, Supplement 33, 49-69.

Ngima Mawoung, G. (2015). Attempts at decentralization, forest management and conservation in Southeast Cameroon. African Study Monographs, 51(1), 143-156.

Njoh, A. J. (2009). Urban planning as a tool of power and social control in colonial Africa. Planning Perspectives, 24(3), 301-317. https://doi.org/10.1080/02665430902933960.

Oksanen, L. (2005). Umpisolmu Mallalla: Ajatuksia ongelman taustasta ja ratkaisumahdollisuuksista. In M. Jokinen (Ed.), Poronhoidon ja suojelun vaikutukset Mallan luonnonpuistossa (Vol. 941, pp. 296-313). Metsäntutkimuslaitoksen tiedonantoja.

Peet, R., \& Watts, M. (Eds.). (2004a). Liberation ecologies: Environment, development, social movements. London: Routledge.

Peet, R., \& Watts, M. (2004b). Liberation ecology: Development, sustainability, and the environment in an age of market triumphalism. In R. Peet \& M. Watts (Eds.), Liberation ecologies: Environment, development, social movements (pp. 1-47). London: Routledge.

Pemunta, N. V. (2013). Governance of nature as development and the erasure of the Pygmies of Cameroon. GeoJournal, 78(2), 353-371.

Pemunta, N. V. (2014). The impact of climate change on food security and health in northern Cameroon. In D. Bigman (Ed.), New developments in global warming research (pp. 1-46). Georgia: Nova Science Publishers.
Pemunta, N. V. (2017). When 'property cannot own property': Women's lack of property rights in Cameroon. African Journal of Economic and Sustainable Development, 6(1), 67-85.

Pemunta, N. V., \& Mbu-Arrey, P. (2013). The tragedy of the governmentality of nature: The case of national parks in Cameroon. In D. Bigman \& J. B. Smith (Eds.), National parks: Sustainable development, conservation strategies, and environmental effects (pp. 1-46). Georgia: Nova Science Publishers.

Pyyhälä, A. (2012). What future for the Baka? Expert Mechanism on the Rights of indigenous peoples side events: Indigenous Peoples' Rights and Livelihood Opportunities in South-East Cameroon. Copenhagen: Eks-Skolens Trykkeri.

Randolph, S., \& Stiles, D. (2011). Elephant meat trade in Central Africa. Gland: UICN.

Rappaport, R. (1968). Pigs for the Ancestors: Ritual in the ecology of a New Guinea people (2nd ed.). New Haven: Yale University Press. (1984).

Ribot, J. C. (1998). Theorizing access: Forest profits along Senegal's charcoal commodity chain. Development and Change, 29(2), 307-341.

Robinson, J., \& Bennet, E. (2000). Hunting for sustainability in tropical forests. Columbia: Columbia University Press.

Rupp, S. (2003). Interethnic relations in Southeastern Cameroon: Challenging the "Hunter-gatherer"-"Farmer" Dichotomy. African Study Monographs, Supplement 28-56, 37-56.

Sarkar, S., \& Montoya, M. (2011). Beyond parks and reserves: The ethics and politics of conservation with a case study from Peru. Biological Conservation, 144(3), 979-988.

Smith, A. E., \& Wishnie, M. (2000). Conservation and subsistence in small-scale societies. Annual Review of Anthropology, 21(1), 493-524.

Stake, R. E. (1995). The art of case study research: Perspective in practice. London: Sage.

Stiles, D. (2011). Elephant meat trade in Central Africa. Summary Report (p. 103). Gland: IUCN.

Tchouaha, S. (2012). Hydropower in Cameroon. Bachelor's Thesis, University of Gävle, Gävle.

Tellis, W. (1997). Introduction to case study. The Qualitative Report, Vol. 3(2), July. http://www.nova.edu/ssss/QR/ QR3-2/tellis1.html.

Usongo, L., \& Nkanje, B. T. (2004). Participatory approaches towards forest conservation: The case of Lobeke National Park, Southeast Cameroon. International Journal of Sustainable Development. World Ecology, 11(2), 119-127.

Vaccaro, I., \& Paquet, P. (2013). Political ecology and conservation policies: Some theoretical genealogies. Journal of Political Ecology, 20(20), 255-272.

Vayda, P., \& Rappaport, R. (1967). Ecology, Cultural and Noncultural. In J. A. Clifton (Ed.), Introduction to cultural anthropology (pp. 477-497). Boston: Houghton and Mifflin.

Vedeld, P., Cavanagh, C., Petursson, J. G., Nakakaawa, C., Moll, R., \& Sjaastad, E. (2016). The political economy of conservation at Mount Elgon, Uganda: Between local deprivation, regional sustainability, and global public goods. Conservation \& Society, 14(3), 183-194. 
Yin, R. K. (2003). Case study research, design and methods (3rd ed., Vol. 5). Thousand Oaks: Sage.

World Parks Congress. (2003). Summary report of the Vth IUCN World Parks Congress: Benefits beyond boundaries, 8-17 September 2003. Available from: http://enb.iisd.org/crs/ worldparksv/sdvol89num9e.html. Accessed 23 May 2017.

United Nations Conference on Environment and Development. (1992). United Nations Conference on Environment \& Development Rio de Janerio, Brazil, 3-14 June 1992 AGENDA 21. Available from: https:// sustainabledevelopment.un.org/content/documents/ Agenda21.pdf.

Wilkie, D. S., \& Carpenter, J. F. (1999). Bush meat hunting in the congo basin: An assessment of impacts and options for mitigation. Biodiversity and Conservation, 8, 927-955. https://doi.org/10.1023/A:1008877309871.

Zainal, Z. (2007). Case study as a research method. Journal Kemanusiaan Bil 9, 1-6. Available from: http://psyking. net/htmlobj-3837/case_study_as_a_research_method.pdf. 